\title{
Phosphate and Potassium Retention and Release during Chrysanthemum Production from Precharged Materials: I. Alumina
}

\author{
Kimberly A. Williams, ${ }^{1}$ Paul V. Nelson, ${ }^{2}$ and Dean Hesterberg ${ }^{3}$ \\ Department of Horticultural Science, North Carolina State University, Raleigh, NC 27695-7609
}

AdDitional Index words. Dendranthema $\times$ grandiflora, soilless substrate, adsorption, isotherm, slow-release fertilizer

\begin{abstract}
Soilless root media have little capacity to retain $\mathrm{PO}_{4}$ or $\mathrm{K}$, and this contributes to leaching of these nutrients during greenhouse crop production. The objective of this research was to evaluate the suitability of precharged alumina as a sole source of $\mathrm{PO}_{4}$ and $\mathrm{K}$ during greenhouse production of potted chrysanthemum [Dendranthema $\times$ grandiflora Kitam. (syn. Chrysanthemum ×morifolium Ramat.)]. Phosphate and $\mathrm{K}$ adsorption and desorption curves were created at $25^{\circ} \mathrm{C}$ for two particle sizes ( 0.5 to 0.9 and 1.8 to $3.2 \mathrm{~mm})$ of alumina $\left(\mathrm{Al}_{2} \mathrm{O}_{3}\right.$; acid-washed and unwashed), and a medium of 7 peat : 3 perlite ( $/ / v)$ using solutions of $\mathrm{KH}_{2} \mathrm{PO}_{4}\left(\mathrm{P}\right.$ at 0 to $\left.20,000 \mathrm{mg} \mathrm{L} \mathrm{L}^{-1}\right)$. Based on these curves, 1.8 to $3.2 \mathrm{~mm}$, unwashed alumina was selected for use in the studies. Precharged alumina was tested in two greenhouse studies at $10 \%$ and $30 \%(\mathrm{v} / \mathrm{v})$ of a peat-perlite medium used to produce 'Sunny Mandalay' chrysanthemum. Phosphate, K, and $\mathrm{pH}$ were determined on unaltered root medium solutions collected throughout the 10-week cropping cycle, and foliar analyses were conducted on tissue collected at the middle and end of the cycle. Potassium release was adequate to meet chrysanthemum demand for 4 weeks, but inadequate for the remainder of the production cycle. Precharged alumina retained and released $\mathrm{PO}_{4}$ at sustained concentrations ( $\mathrm{P}$ at $<2 \mathrm{mg} \cdot \mathrm{L}^{-1}$ ) over the course of a 10-week cropping cycle. Growth of plants receiving $\mathrm{PO}_{4}$ from precharged alumina was not significantly different from the controls receiving liquid fertilizer $\left(P\right.$ at $\left.46.5 \mathrm{mg} \cdot \mathrm{L}^{-1}\right)$ at each watering when precharged alumina comprised $30 \%$ of the medium, and only slightly less when precharged alumina comprised $10 \%$ of the medium. A phosphorus budget showed that while $36 \%(103 \mathrm{mg})$ of the applied $\mathrm{PO}_{4}-\mathrm{P}$ was lost in the leachate of the controls, only $0.1 \%(2 \mathrm{mg})$ was lost from plants produced with alumina-P. This research demonstrates that in a soilless medium with physical properties similar to standard commercial mixes, low but adequate $\mathrm{PO}_{4}$ concentrations can be achieved and sustained using current production practices.
\end{abstract}

The greenhouse industry currently faces the need to substantially reduce the content of nutrients such as $\mathrm{PO}_{4}$ in greenhouse effluent. Eutrophication of surface waters and increasing concern over $\mathrm{PO}_{4}$ in lakes and near coastal waters are major water quality issues that are generating national attention (U.S. Environmental Protection Agency, 1989). This environmental contamination which results in part from $\mathrm{PO}_{4}$ runoff from agricultural areas is one reason for the enactment of restrictive legislation on a broad scale (Pyle, 1991).

Phosphate leaching from containers is a problem because excessive levels of $\mathrm{PO}_{4}$ fertilizer are applied commonly during greenhouse crop production. The typical $\mathrm{PO}_{4}$ nutrition program of heavily fertilized crops like chrysanthemum [Dendranthema $\times$ grandiflora (syn. Chrysanthemum $\times$ morifolium)] frequently includes preplant amendments of superphosphate, followed by liquid fertilizer $\mathrm{PO}_{4}$ applications at high rates (Nelson, 1998).

\footnotetext{
Received for publication 22 July 1999. Accepted for publication 21 June 2000 This research was funded in part by the North Carolina Agricultural Research Service (NCARS), Raleigh, NC 27695-7643 and by a grant from Sun Gro Horticulture, Inc., Bellevue, WA 98009. Use of trade names in this publication does not imply endorsement by the NCARS of products named nor criticism of similar ones not mentioned. We thank William $\mathrm{H}$. Swallow for expert statistical guidance. Appreciation is also extended to Yoder Brothers, Inc., Barberton, Ohio 44203 , for providing rooted stem cuttings of chrysanthemum, and to Aluminum Company of America (Alcoa), Vidalia, LA 71373 for donating alumina materials. From a PhD dissertation submitted by K.A.W. The cost of publishing this paper was defrayed in part by the payment of page charges. Under postal regulations, this paper therefore must be hereby marked advertisement solely to indicate this fact.

${ }^{1}$ Former graduate assistant. Currently: Assistant Professor, Dept. of Horticulture, Forestry, and Recreation Resources, 2021 Throckmorton Plant Sciences Center, Kansas State University, Manhattan, KS 66506-5506.

${ }^{2}$ Professor

${ }^{3}$ Associate professor, Department of Soil Science.
}

Even slow-release fertilizers, applied at standard rates, result in unnecessarily high $\mathrm{PO}_{4}$ concentrations in the root medium solution (Williams and Nelson, 1992) and thus substantial $\mathrm{PO}_{4}$ may be lost through leaching. However, if $\mathrm{PO}_{4}$ is available for plant uptake in accordance with the rate of plant removal, equilibrium $\mathrm{PO}_{4}-\mathrm{P}$ soil solution concentrations as low as $0.2 \mathrm{mg} \cdot \mathrm{L}^{-1}$ are adequate for optimal growth of most plant species (Beckwith, 1965), including chrysanthemum (Nishimoto et al., 1975).

Soilless media commonly used for greenhouse crop production have almost no capacity to adsorb and retain $\mathrm{PO}_{4}$, unlike soils and soil-based media which predate soilless mixes (Marconi and Nelson, 1984). The challenge, therefore, is to develop a commercial solid root medium production system in which low $\mathrm{PO}_{4}$ concentrations are achieved and sustained in the medium solution. Low, relatively constant root medium solution $\mathrm{PO}_{4}$ concentrations theoretically would be maintained if $\mathrm{PO}_{4}$ was released from the root medium exchange sites in direct proportion to plant removal and leaching losses from the medium solution. Such a cultural production system could substantially reduce $\mathrm{PO}_{4}$ losses through leaching. An additional advantage of producing floricultural crops under low $\mathrm{PO}_{4}$ regimes is that these plants may be more tolerant of drought stress (Borch et al, 1998).

One material that could be precharged with $\mathrm{PO}_{4}$ and combined with soilless medium components to accomplish this task is alumina $\left(\mathrm{Al}_{2} \mathrm{O}_{3} \times \mathrm{H}_{2} \mathrm{O}\right)$. Several researchers have used alumina as a component of sand culture and solid-phase buffer systems to maintain low $\mathrm{PO}_{4}$ concentrations in nutrient solutions (Coltman et al., 1982; Elliott et al., 1983; Lynch et al., 1990). Lin et al. (1996) used alumina precharged with $\mathrm{PO}_{4}$ as a component of a 2 peat : 2 vermiculite : 1 sand medium (by volume), with $\mathrm{P}$ alumina substituted for sand at various concentrations to produce African marigolds (Tagetes erecta L.). This approach 
resulted in growth comparable to traditionally fertilized controls, while decreasing $\mathrm{PO}_{4}$ losses through leaching.

Alumina can also retain cations through $\mathrm{pH}$-dependent negative surface charges. The capacity to do so increases with increasing $\mathrm{pH}$ and increasing amounts of specifically adsorbed anions, such as $\mathrm{PO}_{4}$. The negative surface charge of oxide minerals increases substantially as the $\mathrm{pH}$ is raised above the point of zero net proton charge (PZNPC), the $\mathrm{pH}$ where $50 \%$ of the surface hydroxyl groups are deprotonated and negatively charged. The PZNPC of alumina (gamma- $\mathrm{Al}_{2} \mathrm{O}_{3}$ ) is $8.2+0.5$ (Sposito, 1984). Although the bulk solution from a soilless root medium should not have a $\mathrm{pH}$ this high, the higher $\mathrm{pH}$ in localized zones around each alumina particle could be lowered by the effects of the bulk medium solution. Thus, $\mathrm{K}$ would be released and available for plant uptake. Therefore, when alumina is precharged with $\mathrm{PO}_{4}$ from a soluble $\mathrm{P}$ source such as $\mathrm{KH}_{2} \mathrm{PO}_{4}$, $\mathrm{K}$ retention, as well as $\mathrm{PO}_{4}$ adsorption, is possible. Potassium retention and release from alumina during crop production requires evaluation. The objectives of this research were to 1) determine the $\mathrm{PO}_{4}$ and $\mathrm{K}$ release patterns and concentrations from precharged alumina used as a component of a soilless medium during a 10 -week cropping cycle, 2) to determine the quantity of $\mathrm{PO}_{4}$ leached over time from this medium, and 3) determine the effectiveness of precharged alumina in providing $\mathrm{PO}_{4}$ and $\mathrm{K}$ during chrysanthemum production.

\section{Materials and Methods}

Treatment materials. The following particle sizes of alumina were obtained from Alcoa, Vidalia, La.: grade F-1, 0.5 to $0.9 \mathrm{~mm}$ (28 to $48 \mathrm{mesh}$ ); and 1.8 to $3.2 \mathrm{~mm}$ ( 8 to $14 \mathrm{mesh}$ ). The 0.5 to $0.9 \mathrm{~mm}$ particle size has been used in previous studies (e.g., Lin et al., 1996; Lynch et al., 1990); the larger particle size of 1.8 to $3.2 \mathrm{~mm}$ would allow substitution of alumina for other root medium components and maintain physical properties comparable to commercial root media. Acid-washed alumina was prepared by soaking in $1 \mathrm{~mol} \cdot \mathrm{L}^{-1} \mathrm{HCl}(1 \mathrm{~g}$ alumina: $2.5 \mathrm{~mL} \mathrm{HCl})$ for $0.5 \mathrm{~h}$, decanting, and repeating once. The alumina was rinsed with distilled water 10 times and dried at $70{ }^{\circ} \mathrm{C}$. The purpose of acid pretreatment was to standardize the surface charge effects of alumina on $\mathrm{PO}_{4}$ retention, which affects equilibrium desorption $\mathrm{PO}_{4}$ concentration and solution $\mathrm{pH}$ (Elliott, 1989). Unwashed alumina received no preparatory treatment. Unwashed and acid-washed alumina were tested in the laboratory experiments; only unwashed alumina was used in the greenhouse experiments.

LABORATORY EXPERIMENTS. Initial extractions of $\mathrm{P}$ and $\mathrm{K}$ were conducted on alumina to determine levels of these elements present before sorption. Dilute acids $\left(0.05 \mathrm{~mol} \cdot \mathrm{L}^{-1} \mathrm{HCl}\right.$ and $0.0125 \mathrm{~mol} \cdot \mathrm{L}^{-1} \mathrm{H}_{2} \mathrm{SO}_{4}$ ) were used for $\mathrm{P}$ extraction (Olsen and Sommers, 1982) and K was extracted with $\mathrm{NH}_{4} \mathrm{OAc}$ (Knudsen et al., 1982). Phosphate and $\mathrm{K}$ adsorption and desorption curves (also known as isotherms) were obtained by modifying the procedures of Fox and Kamprath (1970). To create adsorption curves, $5 \mathrm{~cm}^{3}$ samples of the treatment materials were measured into $50 \mathrm{~mL}$ centrifuge tubes (sample weight was the same for all replications of each treatment material). Thirty milliliters of $0.01 \mathrm{M} \mathrm{CaCl}_{2}$, which contained $\mathrm{P}$ at $0,500,1000,1500,3000$, 5000,10000 or $20000 \mathrm{mg} \cdot \mathrm{L}^{-1}$ from $\mathrm{KH}_{2} \mathrm{PO}_{4}$ was added to each tube, as well as two drops of toluene to limit microbial growth. The tubes were capped and placed on their sides on a circular motion shaker $(100 \mathrm{rpm})$ for $10 \mathrm{~d}$ at $23{ }^{\circ} \mathrm{C}$. Next, the tubes were centrifuged at $5856 g_{\mathrm{n}}$, and the supernatant solution was removed and analyzed for $\mathrm{PO}_{4}-\mathrm{P}$ using an ultraviolet/visible (UV/VIS) spectrophotometer (Perkin-Elmer, Norwalk, Conn.) following the methods of Chapman and Pratt (1961) for concentrations $>10$ $\mathrm{mg} \cdot \mathrm{L}^{-1}$ or Murphy and Riley (1962) for concentrations <10 $\mathrm{mg} \cdot \mathrm{L}^{-1}$. Potassium was analyzed using atomic absorption spectroscopy. $\mathrm{pH}$ measurements were taken with a combined $\mathrm{pH}$ and temperature meter (Extech Instruments Corp., Waltham, Mass.). Phosphorus that disappeared from solution was considered to be sorbed by the alumina.

To create desorption curves, untreated alumina was charged with $\mathrm{PO}_{4}$ from $\mathrm{KH}_{2} \mathrm{PO}_{4}$ at a $\mathrm{P}$ concentration of $20,000 \mathrm{mg} \cdot \mathrm{L}^{-1}$ as described for the adsorption curves. After a $10 \mathrm{~d}$ equilibration period and volumetric removal of $15 \mathrm{~mL}$ supernatant solution, the removed solution was replaced with $15 \mathrm{~mL} 0.01 \mathrm{M} \mathrm{CaCl}_{2}$. To further reduce the concentration of $\mathrm{PO}_{4}$ in the solution and encourage release of $\mathrm{PO}_{4}$ from the solid phase, a second aliquot of supernatant solution was then removed after inverting the tube several times by hand and centrifuging. Fifteen milliliters $0.01 \mathrm{M}$ $\mathrm{CaCl}_{2}$ and two drops toluene was added, and the tubes were capped and placed on the shaker for a minimum of $9 \mathrm{~h}$ for equilibration. Desorption sampling continued twice daily until 22 desorption events, each consisting of two replacements of supernatant solutions, had been completed. Phosphate, K, and $\mathrm{pH}$ were determined in all supernatant solutions for calculation (by mass balance) of $\mathrm{PO}_{4}$ and $\mathrm{K}$ sorbed, but only results from the first supernatant solution of each desorption event are presented.

GreENhOUSE EXPERIMENTS: GENERAL PROCEDURES. Two experiments were conducted with the following procedures in common. Alumina was precharged with $\mathrm{PO}_{4}$ and $\mathrm{K}$ as described above for adsorption curves except that larger batches of precharged alumina were produced by using the same $1: 6$ solid volume : solution ratio in Erlenmeyer flasks. The concentration of $\mathrm{P}$ from $\mathrm{KH}_{2} \mathrm{PO}_{4}$ at which the materials were precharged was at $3,510 \mathrm{mg} \cdot \mathrm{L}^{-1}$. The precharged alumina was taken through two desorption events before drying and incorporation into the media for the greenhouse experiments. Appropriate volumes of root medium components were measured with a graduated cylinder and then mixed by hand to create the treatment root media.

Rooted stem cuttings of 'Sunny Mandalay' chrysanthemum were potted one cutting per 0.5 -L pot. Root medium was amended with the following materials and rates per liter: $6 \mathrm{~g}$ dolomitic limestone; 0.9 g gypsum; and 0.074 g FTE-555 micronutrient mix (Frit Industries, Ozark, Ala.) in Expt. 1 or 3.3 g Esmigran micronutrient mix (Scotts-Sierra Horticultural Products, Marysville, Ohio) in Expt. 2. The water source had a $\mathrm{pH}=7.0$, $\mathrm{Ca}$ at $10 \mathrm{mg} \cdot \mathrm{L}^{-1}, \mathrm{Mg}$ at $3 \mathrm{mg} \cdot \mathrm{L}^{-1}$, and $\mathrm{Ca}$-carbonate equivalent alkalinity of $25 \mathrm{mg} \cdot \mathrm{L}^{-1}$. Pots were spaced $20 \times 28 \mathrm{~cm}$. Day/night greenhouse temperatures were set at $25 / 17^{\circ} \mathrm{C}$. Treatments were arranged in a randomized complete block design with three blocks and two pots per experimental unit. Data were subjected to analysis of variance procedures (PROC ANOVA, SAS Institute, Cary, N.C.). Least significant differences (LSDs) were calculated to separate treatment means as follows. If the percentage alumina level by fertilizer treatment interaction was significant, a single LSD was calculated to compare means across both percentage alumina levels and fertilizer treatments. If the percentage alumina by fertilizer interaction was nonsignificant, two separate LSD values were calculated, one to compare means across percentage alumina levels and one to compare means across fertilizer treatments.

Unaltered bulk root medium solution was sampled by vacuum 
removal. To accomplish this, fertilizer solutions were applied to pots, allowed to equilibrate for $1 \mathrm{~h}$, then pots were sealed in a suction funnel and a vacuum was drawn on the base of the pot. Ten milliliters of solution was collected from each of the two pots within an experimental unit and combined. Solutions were collected on days 1 (first day after planting), 5, 8, 15, 22, 29, 43, 57, and 70 in Expt. 1 or day 66 in Expt. 2. Media solution samples were analyzed for $\mathrm{PO}_{4}-\mathrm{P}, \mathrm{K}$, and $\mathrm{pH}$. Soluble $\mathrm{Al}$ was determined on unfiltered root medium solution samples collected in Expt. 1 using an inductively coupled argon plasma emission spectrophotometer (Fisons Instruments, Dearborn, Mich.).

Plant height, width, and quality ratings were recorded weekly. Height was measured from the rim of the pot to the top of the foliage or flower canopy and width was the average of two measurements taken at right angles to each other. Plant quality ratings were assigned subjectively after consideration of plant volume, form, foliage color, and number and size of flowers on a scale of 1 to 10 with 7 to 10 representing quality meeting commercial standards and 10 as optimum. Shoot fresh weights and shoot dry weights (dried for a minimum of $48 \mathrm{~h}$ at $70^{\circ} \mathrm{C}$ ) were recorded at the end of the crop.

Tissue samples consisted of the youngest, fully expanded leaves at midcrop and whole shoots at the end of the crop. Shoots were sampled at the end of the experiment so that total nutrient uptake (shoot dry weight $\times$ concentration) could be determined. Mobile elements such as N, P, and K are generally lower in whole shoots compared to recently mature leaves; thus, if whole shoot levels of mobile nutrients are equal to or greater than standards for recently matured leaves, it follows that these nutrients are not deficient. Plant tissue was rinsed under warm tap water, washed for $30 \mathrm{~s}$ in $0.2 \mathrm{~mol} \cdot \mathrm{L}^{-1} \mathrm{HCl}$, rinsed under warm tap water, and rinsed for $30 \mathrm{~s}$ in distilled water. Dried tissue was ground in a stainless steel Wiley mill to pass a 20-mesh (1.3-mm) screen. Tissue used for $\mathrm{P}, \mathrm{K}, \mathrm{Ca}, \mathrm{Mg}, \mathrm{S}, \mathrm{Fe}, \mathrm{Mn}, \mathrm{Zn}$, and $\mathrm{Cu}$ analyses was dry-ashed at $500{ }^{\circ} \mathrm{C}$, dehydrated in $6 \mathrm{~mol} \cdot \mathrm{L}^{-1} \mathrm{HCl}$, and dissolved in $0.5 \mathrm{~mol} \cdot \mathrm{L}^{-1} \mathrm{HCl}$. Tissue used for $\mathrm{S}$ and $\mathrm{B}$ analysis was ashed in the presence of $\mathrm{Mg}\left(\mathrm{NO}_{3}\right)_{2}$ and ethanol at $450^{\circ} \mathrm{C}$ and dissolved in $0.5 \mathrm{~mol} \cdot \mathrm{L}^{-1} \mathrm{HCl}$. Total $\mathrm{N}$ was determined using a microKjeldahl procedure after pretreatment with salicylic acid to aid in the reduction of nitrate (Eastin, 1978). Analysis of $\mathrm{K}, \mathrm{Ca}, \mathrm{Mg}$,
$\mathrm{Fe}, \mathrm{Mn}, \mathrm{Zn}$, and $\mathrm{Cu}$ was conducted using atomic absorption spectroscopy. Phosphorus determination was accomplished by the previously mentioned colorimetric methods. Sulfur was determined by a turbidimetric procedure in which $\mathrm{Ba}\left(\mathrm{SO}_{4}\right)$ was dispersed with polyvinyl pyrolidine (A.H. Hunter, personal communication), and colorimetric analyses were performed for B (Grinstead and Snider, 1967).

Physical properties of bulk density (BD), particle density (PD), air-filled porosity at container capacity (AFP), container capacity (CC), and total porosity (TP) were determined on four replications of fallow pots of each unique medium by using the tube method of Niedziela and Nelson (1992).

GREENHOUSE EXPERIMENT 1: PHOSPHATE AND K RELEASE FROM PRECHARGED ALUMina. Rooted stem cuttings were potted on 2 Feb. 1994. Plants received 2 weeks of long days (lighted from 2200 to $0200 \mathrm{HR}$ with incandescent bulbs) followed by 8 weeks of natural short days, and were pinched 2 weeks after potting to leave nine nodes. Lateral flower buds were removed 5 weeks after pinching. The production cycle was $71 \mathrm{~d}$.

The control plants were grown in a medium of 7 low-humified sphagnum peat : 3 coarse perlite (v/v) (Krum, Silbrico Co., Hodgkins, Ill.). Alumina was incorporated into the medium as $0 \%, 10 \%$, or $30 \%(\mathrm{v} / \mathrm{v})$ of the mix by replacing perlite. The $10 \%$ and $30 \%$ volumes were large compared to those used in other studies (Lin, et al.,1996; Lynch et al., 1990) in an effort to decrease the occurrence of localized $\mathrm{PO}_{4}$ depletion in the rhizosphere. Previous studies indicated that these different volumes of $\mathrm{Al}_{2} \mathrm{O}_{3}$ in the medium should result in the same equilibrium $\mathrm{PO}_{4}$ concentration (Coltman et al., 1982). The treatment structure was factorial with alumina at three rates $(0 \%, 10 \%$, and $30 \%$ by volume of the root medium) by three fertilizer treatments: precharged alumina fertilized with $-\mathrm{P}$ fertilizer, precharged alumina fertilized with $-\mathrm{K}$ fertilizer, and uncharged alumina fertilized with complete fertilizer. The treatment termed complete control consisted of the medium by fertilizer combination of $0 \%$ alumina [ 7 peat : 3 perlite $(\mathrm{v} / \mathrm{v})$ ] and complete fertilizer.

The three fertilizer treatments used each provided $\mathrm{N}$ at 210 $\mathrm{mg} \cdot \mathrm{L}^{-1}$ from the following fertilizers at each watering: the complete fertilizer consisted of $4.5 \mathrm{mM} \mathrm{KNO}_{3}, 1.5 \mathrm{mMNH}_{4} \mathrm{H}_{2} \mathrm{PO}_{4}$, and $4.5 \mathrm{~mm} \mathrm{NH}_{4} \mathrm{NO}_{3}\left(2 \mathrm{NH}_{4}-\mathrm{N}: 3 \mathrm{NO}_{3}-\mathrm{N}\right)$; the $-\mathrm{P}$ fertilizer
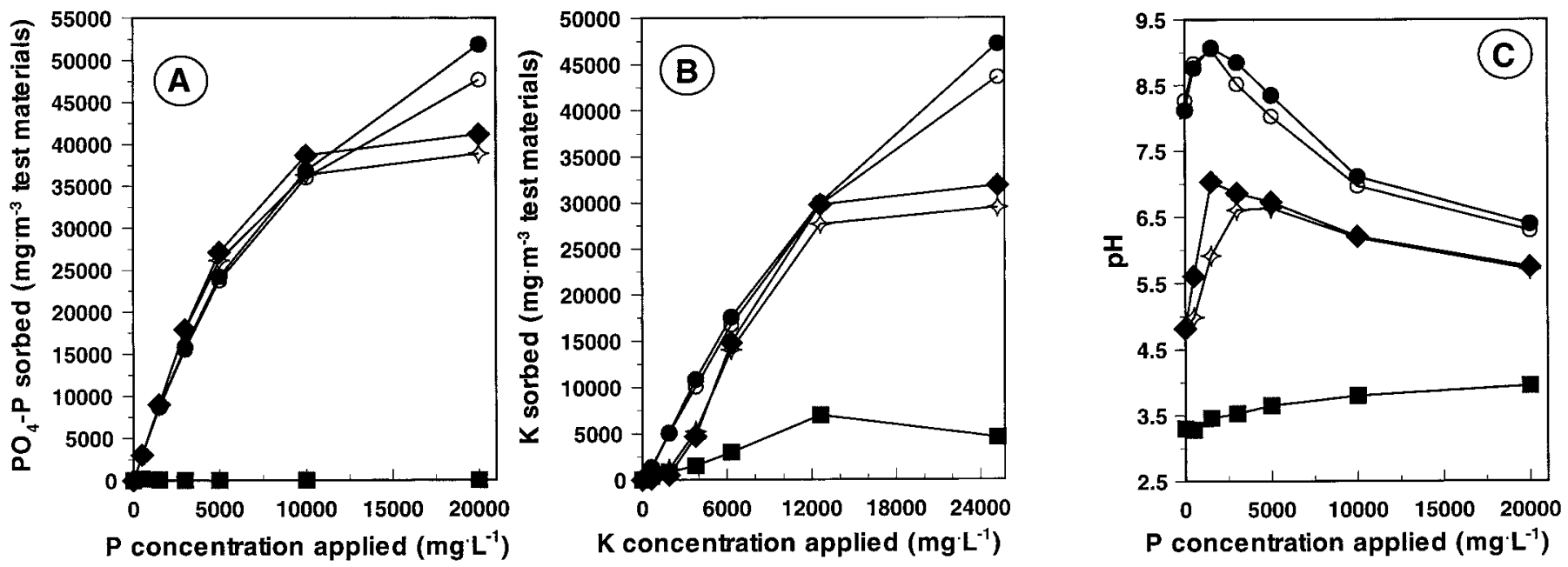

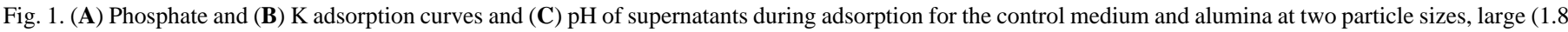

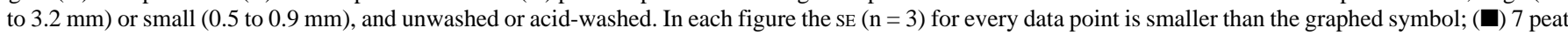
: 3 perlite control medium; $(\bigcirc)$ alumina, large, unwashed; (○) alumina, small, unwashed; $(\diamond)$ alumina, large, acid-washed; and $(\diamond)$ alumina, small, acid-washed. 

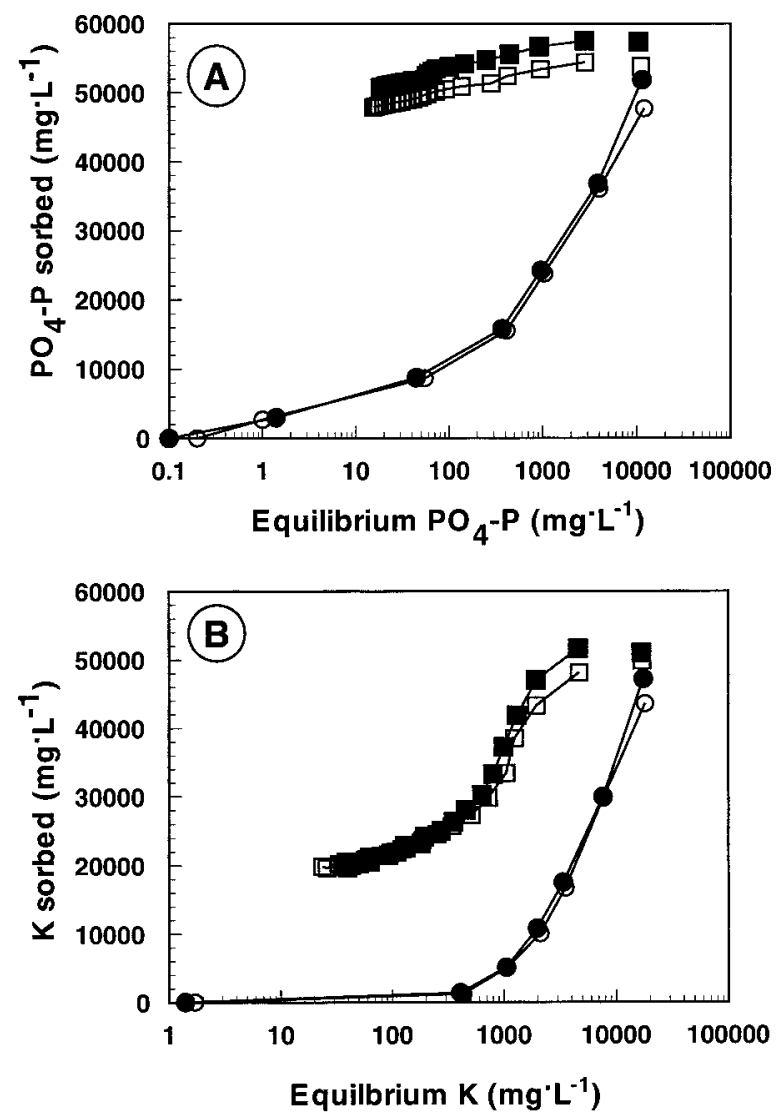

Fig. 2. (A) Phosphate and (B) K adsorption and desorption curves for alumina at two particle sizes, large (1.8 to $3.2 \mathrm{~mm})$ and small (0.5 to $0.9 \mathrm{~mm})$. Unattached desorption points are amounts of $\mathrm{PO}_{4}-\mathrm{P}$ or $\mathrm{K}$ calculated to be adsorbed before beginning desorption. In each figure the SE $(\mathrm{n}=3)$ for every data point is smaller than the graphed symbol; $(\bullet)$ adsorption, large particle size, $(\bigcirc)$ adsorption,

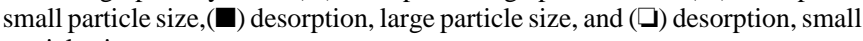
particle size. consisted of $4.5 \mathrm{~mm} \mathrm{KNO}_{3}$ and $5.25 \mathrm{~mm} \mathrm{NH}_{4} \mathrm{NO}_{3}\left(7 \mathrm{NH}_{4}-\mathrm{N}: 13\right.$ $\left.\mathrm{NO}_{3}-\mathrm{N}\right)$; and the $-\mathrm{K}$ fertilizer consisted of $1.5 \mathrm{~mm} \mathrm{NH}_{4} \mathrm{H}_{2} \mathrm{PO}_{4}$ and $6.75 \mathrm{mM} \mathrm{NH}_{4} \mathrm{NO}_{3}\left(11 \mathrm{NH}_{4}-\mathrm{N}: 9 \mathrm{NO}_{3}-\mathrm{N}\right)$. The leaching fraction (LF), defined as the volume of leachate divided by the volume of solution applied, was estimated at 0.2. Plants were watered just as the first plants began to express visible stress symptoms (loss of foliage turgidity).

GREENHOUSE EXPERIMENT 2: PHOSPHORUS BUdGET. Rooted stem cuttings were potted on 17 June 1994. Plants received 2 weeks of natural long days followed by 8 weeks of short days (covered with black cloth from about 1700 to $0800 \mathrm{HR}$ ), and were pinched 1 week after planting to leave nine nodes. Lateral buds were removed 5.5 weeks after pinching. The production cycle was $67 \mathrm{~d}$.

Control plants were grown in the same medium as Expt. 1, 7 peat : 3 perlite $(\mathrm{v} / \mathrm{v})$. Precharged alumina was incorporated into the medium to comprise $0 \%, 10 \%$, and $30 \%$ of the volume, but the peat : perlite ratios were adjusted to result in physical properties more similar to the complete control treatment: 0 alumina : 7 peat : 3 perlite, 1 alumina : 6.5 peat : 2.5 perlite, and 3 alumina : 5.5 peat : 1.5 perlite (by volume).

Two fertilizer treatments were used. The complete fertilizer was identical to the formulation used in Expt. 1 and the $-\mathrm{P}$ fertilizer consisted of $4.5 \mathrm{mM} \mathrm{KNO}_{3}, 4.5 \mathrm{~mm} \mathrm{NH}_{4} \mathrm{NO}_{3}$, and 0.75 $\mathrm{mm}\left(\mathrm{NH}_{4}\right)_{2} \mathrm{SO}_{4}$. Both fertilizers contained $2 \mathrm{NH}_{4}-\mathrm{N}: 3 \mathrm{NO}_{3}-\mathrm{N}$. There were a total of four treatments. The complete fertilizer was applied as the complete control, and the-P fertilizer was applied to plants grown in media consisting of $0 \%, 10 \%$ or $30 \%$ precharged alumina. Plants were watered when the weight of the pots decreased by $40 \%$ of container capacity. A measured volume of $\mathrm{N}$ at $200 \mathrm{mg} \cdot \mathrm{L}^{-1}$ fertilizer solution was applied at each watering to result in a controlled LF of 0.2. To collect the leachate, pots were placed over a 600-mL glass beaker. After allowing the pots to drain completely, leachate was collected in plastic milk jugs to which phenylmercuricacetate was added to prevent microbial growth and stored at $5{ }^{\circ} \mathrm{C}$.

Table 1. Growth measurements for shoot growth at the end of the crop (day 71) of 'Sunny Mandalay' chrysanthemums grown with alumina comprising 0\%, 10\%, and 30\% of the medium (Expt. 1).

\begin{tabular}{|c|c|c|c|c|c|}
\hline $\begin{array}{l}\text { Alumina } \\
(\%)\end{array}$ & $\begin{array}{l}\mathrm{Ht} \\
(\mathrm{cm})\end{array}$ & $\begin{array}{l}\text { Width } \\
(\mathrm{cm})\end{array}$ & $\begin{array}{c}\text { Fresh } \\
\text { wt } \\
(\mathrm{g})\end{array}$ & $\begin{array}{l}\text { Dry } \\
\text { wt } \\
(\mathrm{g})\end{array}$ & Rating $^{z}$ \\
\hline & \multicolumn{5}{|c|}{$-\mathrm{P}$ fertilizer ${ }^{\mathrm{y}}$} \\
\hline 0 & 8.0 & 8.5 & 6.4 & 1.0 & 1.0 \\
\hline 10 & 16.6 & 25.3 & 101.3 & 10.6 & 7.7 \\
\hline \multirow[t]{2}{*}{30} & 17.7 & 26.7 & 124.5 & 13.3 & 8.7 \\
\hline & \multicolumn{5}{|c|}{$-\mathrm{K}$ fertilizer ${ }^{\mathrm{y}}$} \\
\hline 0 & 10.4 & 15.4 & 39.2 & 3.0 & 1.7 \\
\hline 10 & 17.5 & 24.5 & 99.3 & 9.8 & 7.0 \\
\hline \multirow[t]{2}{*}{30} & 17.0 & 26.2 & 108.7 & 11.3 & 7.7 \\
\hline & \multicolumn{5}{|c|}{ Complete fertilizer ${ }^{\mathrm{x}}$} \\
\hline $0^{\mathrm{w}}$ & 20.2 & 30.0 & 162.6 & 16.3 & 10.0 \\
\hline 10 & 19.1 & 29.0 & 141.0 & 13.5 & 9.3 \\
\hline 30 & 16.1 & 22.2 & 79.6 & 7.9 & 6.0 \\
\hline $\operatorname{LSD}_{0.05}{ }^{v}$ & 1.4 & 2.4 & 27.1 & 2.4 & 1.2 \\
\hline
\end{tabular}

${ }^{\mathrm{z}}$ Scale of 1 to 10 with $1=$ death and $10=$ optimum commercial growth.

yUsed with precharged alumina.

${ }^{x}$ Used with uncharged alumina.

${ }^{\mathrm{w}}$ Complete control.

${ }^{{ }}$LSD used to compare fertilizer treatment $(-\mathrm{P},-\mathrm{K}$, or complete) for a given percentage alumina level $(0 \%, 10 \%$, or $30 \%)$ and percentage alumina level for a given fertilizer treatment. Fertilizer treatment, percentage alumina level, and fertilizer by percentage alumina interaction are significant at $P=0.0001$ for height, width, fresh weight, dry weight, and rating. 
Table 2. Mineral nutrient content (dry weight basis) of the youngest fully expanded leaves collected at midcrop (day 42) and whole shoots at end of the crop (day 71) of 'Sunny Mandalay' chrysanthemums grown with alumina comprising 0\%, 10\%, and 30\% of the medium (Expt. 1).

\begin{tabular}{|c|c|c|c|c|c|c|c|c|c|}
\hline \multirow{3}{*}{$\begin{array}{l}\text { Alumina } \\
(\%)\end{array}$} & \multicolumn{9}{|c|}{ Mineral } \\
\hline & $\mathrm{N}$ & $\mathrm{P}$ & $\mathrm{K}$ & $\mathrm{Ca}$ & $\mathrm{Mg}$ & $\mathrm{Fe}$ & $\mathrm{Mn}$ & $\mathrm{Zn}$ & $\mathrm{Cu}$ \\
\hline & \multicolumn{5}{|c|}{$(\%)$} & \multicolumn{4}{|c|}{$\left(\mu \mathrm{g} \cdot \mathrm{g}^{-1}\right)$} \\
\hline & & & & & Midcrop & & & & \\
\hline \multicolumn{10}{|l|}{-P fertilizer ${ }^{\mathrm{z}}$} \\
\hline 0 & 4.19 & 0.06 & 3.52 & 0.62 & 0.41 & 23 & 192 & 111 & 4 \\
\hline 10 & 5.51 & 0.26 & 6.09 & 1.02 & 0.53 & 47 & 184 & 108 & 2 \\
\hline 30 & 5.76 & 0.31 & 5.93 & 1.15 & 0.54 & 42 & 117 & 86 & 4 \\
\hline \multicolumn{10}{|l|}{$-\mathrm{K}$ fertilizer ${ }^{\mathrm{z}}$} \\
\hline 0 & 7.49 & 0.88 & 1.06 & 1.09 & 0.85 & 20 & 295 & 177 & 7 \\
\hline 10 & 6.53 & 0.67 & 1.06 & 1.69 & 1.46 & 39 & 186 & 136 & 4 \\
\hline 30 & 6.31 & 0.49 & 3.44 & 1.67 & 0.92 & 40 & 146 & 87 & 7 \\
\hline \multicolumn{10}{|l|}{ Complete fertilizer } \\
\hline $0^{\mathrm{x}}$ & 6.29 & 0.90 & 5.39 & 0.96 & 0.72 & 69 & 230 & 56 & 3 \\
\hline 10 & 6.15 & 0.41 & 5.95 & 0.88 & 0.65 & 49 & 221 & 42 & 5 \\
\hline 30 & 5.61 & 0.35 & 5.77 & 0.66 & 0.48 & 44 & 157 & 41 & 4 \\
\hline Standards ${ }^{\mathrm{w}}$ & 4.00 & 0.25 & 4.00 & 1.00 & 0.25 & 50 & 50 & 20 & 6 \\
\hline \multirow{2}{*}{$\mathrm{LSD}_{0.05}$} & $0.53^{\mathrm{v}}$ & $0.05^{v}$ & $0.54^{v}$ & $0.20^{\mathrm{v}}$ & $0.13^{v}$ & $12^{\mathrm{v}}$ & $39^{\mathrm{u}}$ & $35^{v}$ & $\mathrm{NS}^{\mathrm{u}}$ \\
\hline & & & & & & & $\mathrm{NS}^{\mathrm{t}}$ & & $2^{t}$ \\
\hline \multicolumn{10}{|l|}{ Significance } \\
\hline Fertilizer treatment & $* * * *$ & $* * * *$ & $* * * *$ & $* * * *$ & $* * * *$ & $* * * *$ & NS & $* *$ & $*$ \\
\hline$\%$ alumina level & NS & $* * * *$ & $* * * *$ & $* * * *$ & $* * * *$ & NS & $* * *$ & $* * * *$ & NS \\
\hline \multirow[t]{2}{*}{ Fertilizer $\times$ alumina $(\%)$} & $* * * *$ & $* * * *$ & $* * * *$ & $* * * *$ & $* * * *$ & $* * * *$ & NS & $*$ & NS \\
\hline & \multicolumn{9}{|c|}{ End crop } \\
\hline \multicolumn{10}{|l|}{$-\mathrm{P}$ fertilizer ${ }^{2}$} \\
\hline 0 & 3.23 & 0.14 & 3.18 & 0.65 & 0.27 & 74 & 116 & 214 & 5 \\
\hline 10 & 3.66 & 0.29 & 4.91 & 1.35 & 0.46 & 100 & 87 & 107 & 5 \\
\hline 30 & 3.78 & 0.34 & 5.25 & 1.59 & 0.46 & 77 & 62 & 80 & 5 \\
\hline \multicolumn{10}{|l|}{$-\mathrm{K}$ fertilizer ${ }^{\mathrm{Z}}$} \\
\hline 0 & 5.65 & 1.04 & 0.66 & 2.00 & 1.12 & 97 & 266 & 361 & 8 \\
\hline 10 & 4.72 & 0.76 & 0.87 & 1.93 & 1.09 & 75 & 99 & 147 & 5 \\
\hline 30 & 4.25 & 0.62 & 1.67 & 1.81 & 0.84 & 77 & 71 & 89 & 7 \\
\hline \multicolumn{10}{|l|}{ Complete fertilizer ${ }^{\mathrm{y}}$} \\
\hline $0^{\mathrm{x}}$ & 4.40 & 0.84 & 4.29 & 0.96 & 0.53 & 63 & 194 & 93 & 9 \\
\hline 10 & 4.73 & 0.45 & 4.95 & 0.96 & 0.51 & 85 & 201 & 48 & 6 \\
\hline 30 & 4.36 & 0.38 & 4.89 & 0.97 & 0.45 & 88 & 223 & 55 & 8 \\
\hline Standards ${ }^{\mathrm{w}}$ & 4.00 & 0.20 & 1.00 & 0.50 & 0.10 & 20 & 25 & 5 & 5 \\
\hline $\mathrm{LSD}_{0.05}$ & $0.58^{\mathrm{v}}$ & $0.08^{\mathrm{v}}$ & $0.50^{\mathrm{u}, \mathrm{t}}$ & $0.27^{v}$ & $0.11^{\mathrm{v}}$ & $\mathrm{NS}^{\mathrm{y}}$ & $34^{v}$ & $61^{v}$ & $2^{u, t}$ \\
\hline \multicolumn{10}{|l|}{ Significance } \\
\hline Fertilizer treatment & $* * * *$ & $* * * *$ & $* * * *$ & $* * * *$ & $*$ & NS & $* * * *$ & $* * * *$ & $* *$ \\
\hline$\%$ alumina level & NS & $* * * *$ & $* *$ & $* *$ & $* * * *$ & NS & $* * * *$ & $* * * *$ & $*$ \\
\hline Fertilizer $\times$ alumina $(\%)$ & $* *$ & $* * * *$ & NS & $* * * *$ & $* *$ & NS & $* * * *$ & $* * *$ & NS \\
\hline
\end{tabular}

$\overline{\mathrm{z}}$ Used with precharged alumina.

y Used with uncharged alumina.

${ }^{x}$ Complete control.

${ }^{w}$ Minimum critical standards for recently matured leaves, for comparative purposes only (Mills and Jones, 1996).

${ }^{\mathrm{v}}$ LSD used to compare fertilizer treatment $(-\mathrm{P},-\mathrm{K}$ or complete) for a given percent alumina level $(0 \%, 10 \%$, or $30 \%)$ and percent alumina level for a given fertilizer treatment; fertilizer $\times$ percent alumina interaction is significant.

${ }^{u_{L S D}}$ used to compare percent alumina levels for a given fertilizer treatment; fertilizer $\times$ percent alumina interaction is nonsignificant. ${ }^{t}$ LSD used to compare fertilizer treatments for a given percent alumina level; fertilizer $\times$ percent alumina interaction is nonsignificant. Ns, $, * * *, * * * * * * * *$ Nonsignifcant or significant at $P=0.05,0.01,0.001$, or 0.0001 , respectively.

\section{Results and Discussion}

LABORATORY EXPERIMENTS. The adsorption curves (Fig. 1) indicated that the 7 peat: 3 perlite medium did not retain $\mathrm{PO}_{4}$, and capacity to retain $\mathrm{K}$ was limited in the $\mathrm{pH}$ range of supernatant solutions in this study (Fig. 1). All alumina treatments had a higher capacity to retain $\mathrm{PO}_{4}$ and $\mathrm{K}$ (Fig. 1). The overlapping curves for treatments with large and small particle size fractions indicated little difference in the amount of $\mathrm{PO}_{4}$ or $\mathrm{K}$ retention at lower P concentrations (Fig. 1A and B). Similarly, acid-washed and unwashed alumina resulted in comparable curves for $\mathrm{PO}_{4}$ and $\mathrm{K}$ retention, although the curves differed at a $\mathrm{P}$ concentration of $20,000 \mathrm{mg} \cdot \mathrm{L}^{-1}\left(\mathrm{~K}\right.$ at $25,250 \mathrm{mg} \cdot \mathrm{L}^{-1}$ ), whereas acid-washed alumina resulted in lower sorbed $\mathrm{PO}_{4}$ and $\mathrm{K}$.

Acid pretreatment resulted in a slightly lower $\mathrm{pH}$ in the supernatant solution than unwashed alumina (Fig. 1C). The 

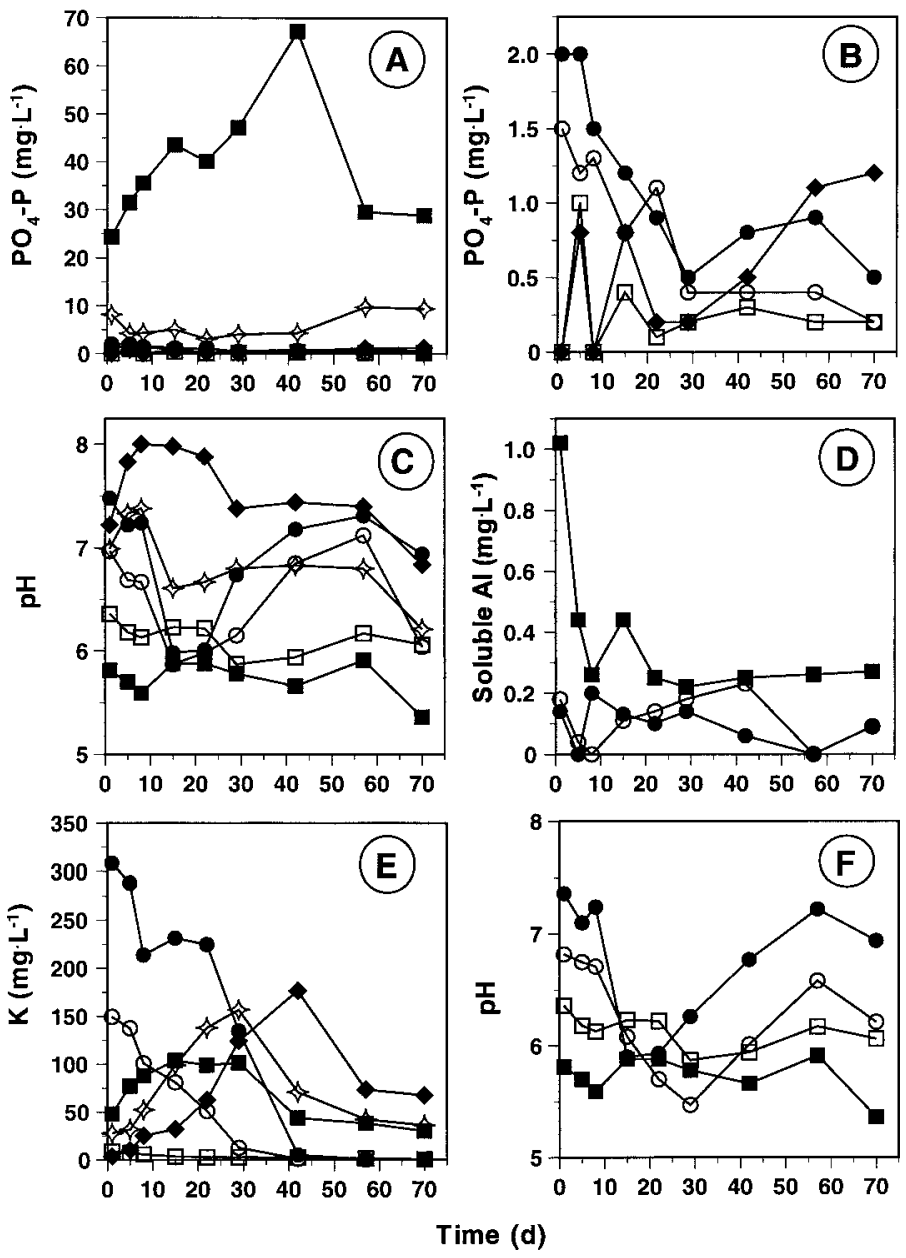

Fig. 3. Mineral nutrient concentrations of unaltered bulk root medium solution during greenhouse Expt. 1 of root media treated with precharged and uncharged alumina. ( $\mathbf{A}$ and $\mathbf{B}) \mathrm{PO}_{4}-\mathrm{P}(\mathrm{SE}=1.0),(\mathbf{C}) \mathrm{pH}$ for precharged alumina with $-\mathrm{P}$ fertilizer and uncharged treatments $(\mathrm{SE}=0.2),(\mathbf{D})$ soluble $\mathrm{Al}$ for precharged alumina with $-\mathrm{P}$ fertilizer treatments, $(\mathrm{SE}=0.1),(\mathbf{E}) \mathrm{K}$ for precharged alumina with $-\mathrm{K}$ fertilizer and uncharged treatments, $(\mathrm{SE}=7.3)$, and $(\mathbf{F}) \mathrm{pH}$ for precharged alumina with $-\mathrm{K}$ fertilizer treatments, $(\mathrm{SE}=0.2)$; $(\boldsymbol{\square})$ complete control, $(\square) 0 \%$ precharged alumina, $(\bigcirc) 10 \%$ precharged alumina, $(\bigcirc) 30 \%$ precharged alumina, $(\diamond)$ 10\% uncharged alumina, and $(\diamond)$ 30\% uncharged alumina. In all figures each symbol is based on three observations (two plants were used to obtain each observation).

higher initial $\mathrm{pH}$ level of unwashed alumina could potentially enhance retention of $\mathrm{K}$ by increasing negative surface charge, and eliminating the acid pretreatment would make the use of alumina easier and more commercially feasible. Therefore, unwashed alumina was used for the greenhouse experiments.

The curves for $\mathrm{PO}_{4}-\mathrm{P}$ and $\mathrm{K}$ desorption from alumina (Fig. 2) showed that large and small particle-size fractions have similar sorption characteristics (Fig. 2); therefore, the large particle size was used in greenhouse studies because at $10 \%$ and $30 \%$ volumes, it resulted in more suitable physical properties in media. The difference between the adsorption and desorption phases of the curves demonstrated that for alumina, $\mathrm{PO}_{4}$ solubility is greater when $\mathrm{PO}_{4}$ is being added to the system than when it is being withdrawn.

For the large particle size, the $\mathrm{pH}$ of the supernatant solution during desorption ranged from a high of 6.5 on the second desorption event to an equilibrium $\mathrm{pH}$ around 5.8 after desorption event 8 (data not presented). Release of $\mathrm{K}$ from the alumina decreased as the $\mathrm{pH}$ approached equilibrium. These trends suggested that as the $\mathrm{pH}$ decreased and $\mathrm{pH}$-dependent charge became more positive, $\mathrm{K}$ was released $\left(\mathrm{H}^{+}-\mathrm{K}^{+}\right.$exchange) from the alumina. The desorption curves suggested that $\mathrm{PO}_{4}$ and $\mathrm{K}$ would be released by alumina during greenhouse production, and the sorption capacity of this mineral suggested that it could maintain $\mathrm{PO}_{4}$ and $\mathrm{K}$ at dissolved concentrations $<1 \mathrm{mg} \cdot \mathrm{L}^{-1}$ and 10 $\mathrm{mg} \cdot \mathrm{L}^{-1}$, respectively.

GREENHOUSE EXPERIMENT 1. Plants receiving $\mathrm{PO}_{4}$ only from $10 \%$ and $30 \%$ precharged alumina grew less than the complete controls based on all criteria (Table 1). However, less growth was not due necessarily to a deficiency of $\mathrm{PO}_{4}$ because levels of $\mathrm{P}$ above the accepted standard minimum critical levels of $0.25 \%$ at midcrop and $0.23 \%$ at end of the crop were recovered in the tissue of plants receiving $\mathrm{PO}_{4}$ only from precharged alumina (Table 2). The higher $\mathrm{P}$ levels recovered in the complete control may indicate luxury consumption from overapplication of $\mathrm{PO}_{4}$. Adequate levels of all other essential nutrients were found at midcrop and end of the crop in the complete control and plants grown with $\mathrm{PO}_{4}$ only from precharged alumina with inconsequential exceptions, including $\mathrm{S}$ and $\mathrm{B}$ (data not presented). Thus, it can be argued that reduction of growth in plants grown with $\mathrm{PO}_{4}$ from precharged alumina was possibly not due to lack of nutrient availability.

The root medium solution $\mathrm{PO}_{4}$ concentrations for plants grown with $\mathrm{PO}_{4}$ only from precharged alumina were apparently adequate throughout the cropping cycle. Concentrations stayed above the minimum critical P level of $0.2 \mathrm{mg} \cdot \mathrm{L}^{-1}$ established by Beckwith (1965) and Nishimoto et al. (1975) (Fig. 3A and B).

One possible explanation for reduced growth was the effect on nutrient availability of the elevated $\mathrm{pH}$ levels of the medium solutions of plants fertilized with the-Pfertilizer $(0 \%, 10 \%$ and $30 \%$ precharged alumina) as compared to the complete control (Fig. 3C). High $\mathrm{pH}$ may result in decreased availability of $\mathrm{PO}_{4}$ or micronutrient cations. While the elevated $\mathrm{pH}$ level could have been a direct effect of the uncharged alumina, it might also have been due to the differences in fertilizer formulations of the complete and -P fertilizers. The complete fertilizer contained a higher percentage $\mathrm{NH}_{4}-\mathrm{N}$ than the -P fertilizer. This would tend to result in development of a lower $\mathrm{pH}$ over the course of the cropping cycle due to the acidifying effects of nitrification and release of $\mathrm{H}^{+}$by the plant into the root medium solution during $\mathrm{NH}_{4}{ }^{+}$uptake. In Expt. 2, these fertilizers were altered to provide the same $\mathrm{NH}_{4}: \mathrm{NO}_{3}$ ratio; the ions that were varied were $\mathrm{Ca}$ and $\mathrm{SO}_{4}$.

To explore the possibility that toxic concentrations of $\mathrm{Al}$ from alumina reduced growth, $\mathrm{Al}$ in the root medium solution was measured (Fig. 3D). Results showed that $\mathrm{Al}$ recovered in the medium solution of the treatments with precharged alumina was lower than in the nontreated complete control, indicating that soluble $\mathrm{Al}$ and/or Al-organic matter complexes were not likely a problem at the $\mathrm{pH}$ of the medium solutions in this study. Based upon observations of root systems, Lin et al. (1996) reported that Al toxicity may have occurred in their studies when the root medium consisted of $12 \%$ and $16 \%(\mathrm{v} / \mathrm{v})$ alumina. Their observations are not supported by results herein.

Differences in physical properties existed between the control mix and those consisting of $10 \%$ and $30 \%$ alumina (Table 3 ) thus providing a third possible explanation for reduced growth. In general, AFP decreased and BD increased as percentage of alumina in the mix increased, making the mixes tighter and less aerated. This was accentuated by watering all plants on the same schedule instead of when a specific gravimetric water content was reached. The mixes were reformulated for Expt. 2 by 
Table 3. Physical property characteristics of root medium formulations used in Expts. 1 and 2 as measured in a 10-cm-deep, 10-cm-round, 0.5-L plastic pot following the procedures of Niedziela and Nelson (1992).

\begin{tabular}{|c|c|c|c|c|c|}
\hline $\begin{array}{l}\text { Medium } \\
(\mathrm{v} / \mathrm{v})\end{array}$ & $\begin{array}{c}\text { Bulk } \\
\text { density } \\
\left(\mathrm{g} \cdot \mathrm{cm}^{-3}\right)\end{array}$ & $\begin{array}{l}\text { Particle } \\
\text { density } \\
\left(\mathrm{g} \cdot \mathrm{cm}^{-3}\right)\end{array}$ & $\begin{array}{l}\text { Air-filled } \\
\text { porosity } \\
\text { (\% by vol) }\end{array}$ & $\begin{array}{l}\text { Container } \\
\text { capacity } \\
\text { (\% by vol) }\end{array}$ & $\begin{array}{c}\text { Total } \\
\text { porosity } \\
\text { (\% by vol) }\end{array}$ \\
\hline & \multicolumn{5}{|c|}{ Expt. 1} \\
\hline 7 peat : 3 perlite & 0.17 & 0.96 & 11.7 & 68.0 & 79.7 \\
\hline 7 peat : 2 perlite : 1 alumina & 0.29 & 1.91 & 8.5 & 74.2 & 82.7 \\
\hline 7 peat : 3 alumina & 0.50 & 3.06 & 6.6 & 74.9 & 81.5 \\
\hline \multirow[t]{2}{*}{$\mathrm{LSD}_{0.05}$} & 0.06 & 0.49 & 3.4 & 3.0 & NS \\
\hline & \multicolumn{5}{|c|}{ Expt. 2} \\
\hline 7 peat $: 3$ perlite & 0.20 & 2.20 & 13.3 & 74.8 & 88.1 \\
\hline 6.5 peat : 2.5 perlite: 1 alumina & 0.24 & 2.48 & 16.9 & 69.8 & 86.6 \\
\hline 5.5 peat : 1.5 perlite $: 3$ alumina & 0.40 & 2.35 & 12.1 & 68.6 & 80.7 \\
\hline $\mathrm{LSD}_{0.05}$ & 0.04 & NS & NS & 4.5 & NS \\
\hline
\end{tabular}

${ }^{\text {NsNonsignificant. }}$

adjusting the peat : perlite ratios to increase AFP in the aluminacontaining mixes.

Although the LF was estimated to be 0.2 in Expt. 1, the method of watering did not allow for careful control. In Expt. 2, to improve the accuracy of leaching and to water each treatment based on individual need, the method of watering was changed as described in the materials and methods. By doing this, any differences in available water of the different media were corrected.

Medium solution Klevels show that release of K from precharged alumina is substantial, but not excessive for the first $25 \mathrm{~d}$ of the cropping cycle (Fig. 3E) based on the standards of Warncke and Krauskopf (1983). By day 43, soluble concentrations of K decreased below $10 \mathrm{mg} \cdot \mathrm{L}^{-1}$ for both treatments which received K only from precharged alumina, a level that was inadequate to meet plant demands. During the initial period of $\mathrm{K}$ release, $\mathrm{pH}$ of the medium solution in treatments of precharged alumina with $-\mathrm{K}$ fertilizer was between 6.7 and 7.5 (Fig. 3F). By day 25 to $30, \mathrm{pH}$ was 5.5 to 5.8 in these treatments. Near the end of the experiment, $\mathrm{pH}$ of these treatments had increased to between 6.5 and 7.5 (Fig. 3F). It was possible that the precharged alumina released $\mathrm{K}$ into the medium solution during the $\mathrm{pH}$ decline of the first part of the cropping cycle, and as the sites which initially held $\mathrm{K}$ were emptied, $\mathrm{H}^{+}$from the medium solution was sorbed by the alumina. This may have resulted in the $\mathrm{pH}$ increase observed in the medium solution. Growth and tissue data (Tables 1 and 2) verify that while precharged alumina met some of the Kneeds of the crop, it could not sustain its release to meet chrysanthemum demands at midcrop and later.

Growth characteristics of plants grown in $10 \%$ uncharged alumina were significantly different from the complete control in only dry weight. However, plants grown in $30 \%$ uncharged alumina were significantly smaller based on all growth characteristics (Table 1). Graphs of medium solution $\mathrm{PO}_{4}$ and $\mathrm{K}$ levels (Fig. 3A, B, and E) suggested that the uncharged alumina removed portions of these nutrients from solution until sorption sites were saturated, making them unavailable for plant uptake. Plants may have been deficient in $\mathrm{PO}_{4}$ and $\mathrm{K}$ until the alumina became saturated. Although data are not available to support this supposition, the uncharged alumina could also have retained other cations from the soluble fertilizer applications early in the cropping cycle, such as $\mathrm{NH}_{4}-\mathrm{N}$, rendering them unavailable for plant uptake. Such a sorption process would help explain the reduction in growth of plants in uncharged alumina.

GREENHOUSE EXPERIMENT 2. Growth of plants that received $\mathrm{PO}_{4}$ only from precharged alumina was similar to the complete control when alumina made up $30 \%$ of the medium, but was significantly less based on three of the five growth measurements when it made up $10 \%$ of the medium (Table 4). The medium solution $\mathrm{PO}_{4}$ concentrations were again below $1.5 \mathrm{mg} \cdot \mathrm{L}^{-1}$ in treatments with precharged alumina (Fig. 4A and B). These low medium solution $\mathrm{PO}_{4}$ concentrations were evidently sufficient to meet chrysanthemum demand based on tissue $\mathrm{P}$ concentration, which exceeded minimum critical levels at both midcrop and end of the crop (Table 5). This confirms that $\mathrm{PO}_{4}$ concentrations do not have to be high in the medium solution to achieve optimal plant growth, but they must be sustained. Elliott (1989) reported that dry matter accumulation in corn (Zea mays L.) increased with increasing percentage of precharged alumina in sand : alumina mixes while the $\mathrm{PO}_{4}$ concentrations in the medium solutions were not significantly affected by percentage alumina. Results of this experiment reaffirmed that observation. While the $\mathrm{PO}_{4}$ concentrations in the medium solution were not substantially different (Fig. 4B), it is speculated that the increase in distribution of the precharged alumina particles throughout the medium at $30 \%$ volume may have increased the effectiveness of $\mathrm{PO}_{4}$ diffusion to the plant and reduced the occurrence of localized zones of $\mathrm{PO}_{4}$ depletion in the rhizosphere. A similar result may occur if lesser volumes of a smaller particle size alumina (e.g., 0.5 to $0.9 \mathrm{~mm}$ ) are used because the smaller particles can be distributed more uniformly throughout the medium at lesser volumes. Tissue $\mathrm{K}$ concentrations in plants grown with precharged alumina (Table 5) were significantly greater than in the complete

Table 4. Plant g rowth characteristics for shoots at end ofthe crop (day 670 of 'Sunny Mandalay' chrysanthemums grown with precharged alumina comprising $0 \%, 10 \%$, and $30 \%$ of the medium (expt. 2).

\begin{tabular}{|c|c|c|c|c|c|}
\hline $\begin{array}{l}\text { Alumina } \\
(\%)\end{array}$ & $\begin{array}{l}\mathrm{Ht} \\
(\mathrm{cm})\end{array}$ & $\begin{array}{l}\text { Width } \\
(\mathrm{cm})\end{array}$ & $\begin{array}{l}\text { Fresh wt } \\
(\mathrm{g})\end{array}$ & $\begin{array}{l}\text { Dry wt } \\
(\mathrm{g})\end{array}$ & Rating $^{z}$ \\
\hline \multicolumn{6}{|c|}{ Complete fertilizer } \\
\hline $0^{\mathrm{y}}$ & 22.3 & 38.5 & 144.7 & 16.1 & 10.0 \\
\hline \multicolumn{6}{|c|}{$-P$ fertilizer ${ }^{x}$} \\
\hline 0 & 14.7 & 17.2 & 13.7 & 3.3 & 2.0 \\
\hline 10 & 20.6 & 33.0 & 109.8 & 13.8 & 9.3 \\
\hline 30 & 22.0 & 37.9 & 141.7 & 15.7 & 10.0 \\
\hline $\mathrm{LSD}_{0.05}$ & 2.5 & 1.3 & 18.2 & 2.8 & 0.6 \\
\hline
\end{tabular}


control. This can be attributed to the release of $\mathrm{K}$ from the precharged alumina as described in Expt. 1 .

The $\mathrm{pH}$ of the root medium solution from plants grown with precharged alumina was still $\approx 1.5$ to 2 units higher than in the complete control plants (Fig. 4C), similar to results in Expt. 1 (Fig. $3 \mathrm{C})$. Based on these data, we believe that the differences in fertilizer $\mathrm{NH}_{4}: \mathrm{NO}_{3}$ ratio had little effect on medium $\mathrm{pH}$ compared to the effects of the alumina.

In Expt. 1, $\mathrm{PO}_{4}$ from $30 \%$ precharged alumina did not result in growth similar to the complete control (Table 1), but it did in Expt. 2. This success in Expt. 2 may have been attributed to improved aeration in the root medium due to the change in media formulation and/or the more carefully controlled leaching and watering procedures which resulted in avoidance of overwatering some treatment plants.

The nutrient budget data from Expt. 2 (Table 6) indicated that $36 \%(103 \mathrm{mg})$ of the applied $\mathrm{PO}_{4}-\mathrm{P}$ of the complete control treatment was lost in the leachate, compared to only $0.1 \%(1 \mathrm{mg})$ for the precharged alumina treatments. However, the majority of the $\mathrm{PO}_{4}$ applied as precharged alumina was fixed in the pots and not utilized during crop production. While this is not an advantage for production of potted flowering crops, sustained release of $\mathrm{PO}_{4}$ may be useful in cut flower production and in interiorscapes where the root medium sustains plant growth for several crops or many years. With $36 \%$ of the applied $\mathrm{PO}_{4}$ recovered in the leachate of the complete control ( $\mathrm{P}$ at $46.5 \mathrm{mg} \cdot \mathrm{L}^{-1} \mathrm{CLF}$ ), the budget suggests that the concentration of $\mathrm{PO}_{4}$ applied during routine water-soluble fertilization could be reduced, perhaps by as much as $40 \%$.

Use of precharged alumina in soilless container media can sustain low concentrations of $\mathrm{PO}_{4}$ that meet chrysanthemum needs during production. Its potential for use by the floricultural industry may be limited by its cost (currently $\$ 0.24 / \mathrm{kg}$ ). In addition, the heavier bulk density may increase shipping and handling costs of both media and finished crops. Another limitation of this system is that the majority of applied $\mathrm{PO}_{4}$ remained

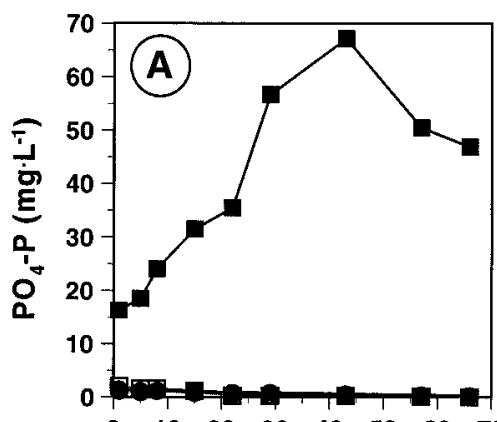

Fig. 4.Phosphate concentration and $\mathrm{pH}$ of unaltered bulk root medium solution during greenhouse Expt. 2 of root media treated with precharged alumina. (A and $\mathbf{B})$ $\mathrm{PO}_{4}-\mathrm{P}(\mathrm{SE}=1.0)$, and $(\mathbf{C}) \mathrm{pH}(\mathrm{SE}$ $=0.1) ;(\square)$ complete control; $(\square)$ $0 \%$ precharged alumina; $(\mathrm{O})$ $10 \%$ precharged alumina; and (๑) $30 \%$ precharged alumina. In all figures each symbol is based on three observations (two plants were used to obtain each observation).
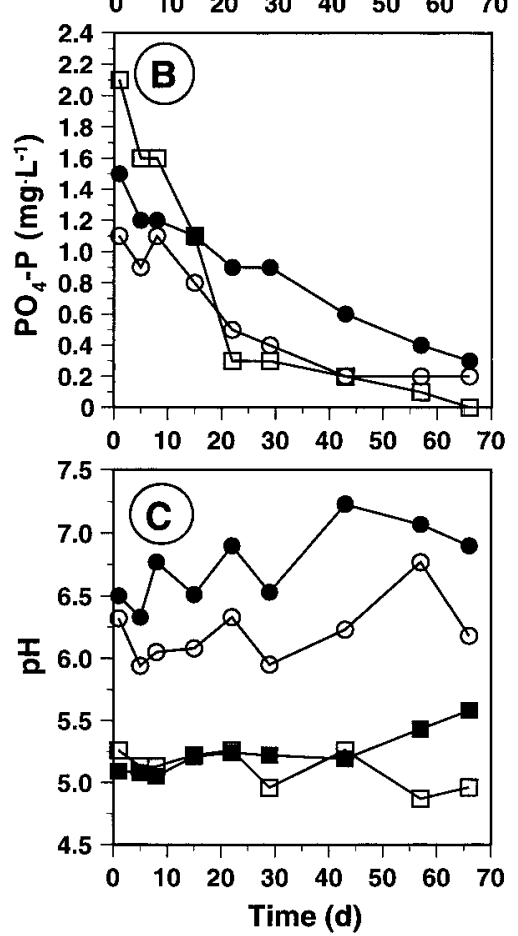

Table 5. Mineral nutrient content (dry weight basis) of the youngest fully expanded leaves collected at midcrop (day 36) and whole shoots at end of the crop (day 67) of 'Sunny Mandalay' chrysanthemums grown with precharged alumina comprising 0\%, 10\%, and 30\% of the medium (Expt. 2).

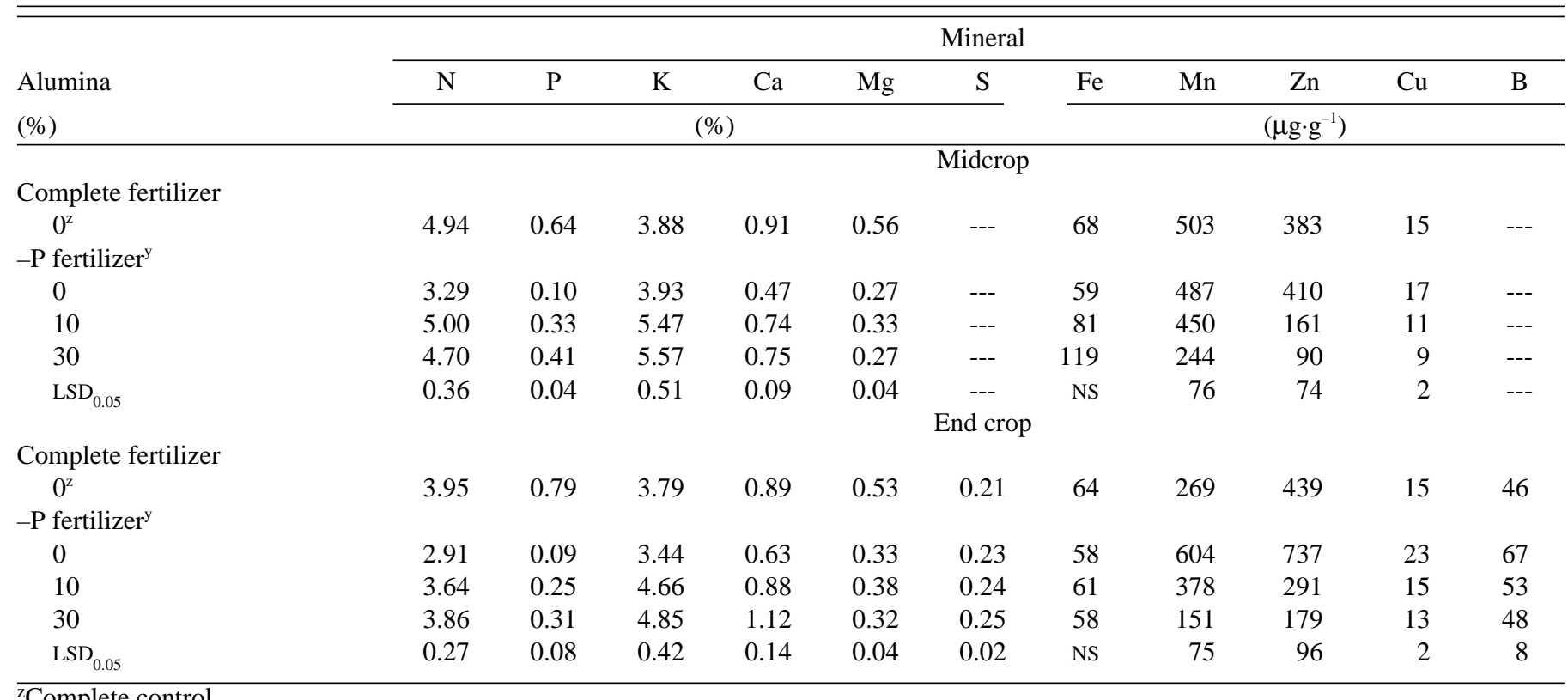

${ }^{\mathrm{z}}$ Complete control.

yUsed with precharged alumina.

NSNonsignificant. 
Table 6. Average proportion of added P recovered in the leachate, of 'Sunny Mandalay' chrysanthemums, or estimated to remain in pots from treatments with alumina comprising $0 \%, 10 \%$, and $30 \%$ of the medium (Expt. 2).

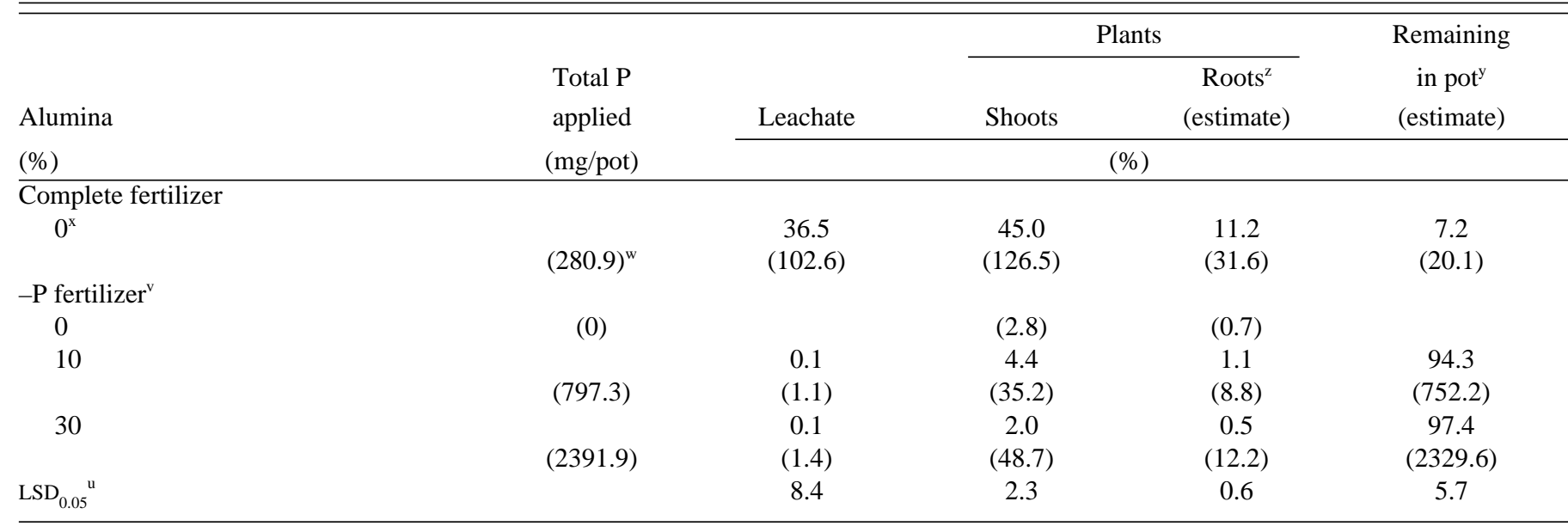

$\overline{\mathrm{z}}$ Liberal estimation of $\mathrm{P}$ in roots was calculated by assuming that root weight was $25 \%$ of the shoot dry weight and P concentration in roots was the same as in tops.

${ }^{y}$ Calculated by subtracting $\mathrm{P}$ recovered in plants and leachate from the total applied.

${ }^{\mathrm{x}}$ Complete control.

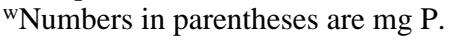

vUsed with precharged alumina.

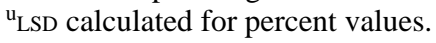

unused after a 10-week cropping cycle. However, the system offers the advantages of a simplified fertilization program for growers and dramatically reduced $\mathrm{PO}_{4}$ losses to the environment from open production systems. In addition, the mechanism of nutrient release would probably be appropriate for use in closed systems such as subirrigation. This research confirms that in a soilless root medium, with physical properties similar to standard commercial mixes, low but adequate $\mathrm{PO}_{4}$ concentrations can be achieved and sustained using current production practices. Therefore, steady-state nutrition in a soilless mix, and its resulting lower nutrient concentrations and reduction in losses from leaching, is a feasible goal for the future.

\section{Literature Cited}

Beckwith, R.S. 1965. Sorbed phosphate at standard supernatant concentration as an estimate of the phosphate needs of soils. Austral. J. Expt. Agr. Animal Husb. 5:52-58.

Borch, K., K.M. Brown, and J.P. Lynch. 1998. Improving bedding plant quality and stress resistance with low phosphorus. HortTechnology 8:575-579.

Chapman, H.D. and P.F. Pratt. 1961. Methods of analysis for soils, plants, and waters. Div. Agr. Sci., Univ. Calif., Riverside, p. 169-170.

Coltman, R.R., G.C. Gerloff, and W.H. Gabelman. 1982. A sand culture system for simulating plant responses to phosphorus in soil. J. Amer. Soc. Hort. Sci. 107:938-942.

Eastin, E.F. 1978. Total nitrogen determination for plant material containing nitrate. Anal. Biochem. 85:591-594.

Elliott, G.C. 1989. Evaluation of sand-alumina-P media for studies of P nutrition. J. Plant Nutr. 12:265-278.

Elliott, G.C., R.M. Carlson, and A. Lauchli. 1983. A solid-phase buffer technique to maintain low concentrations of phosphate in nutrient solutions. J. Plant Nutr. 6:1043-1058.

Fox, R.L. and E.J. Kamprath. 1970. Phosphate sorption isotherms for evaluating the phosphate requirements of soils. Soil Sci. Soc. Amer. Proc. 34:902-906.

Grinstead, R.R. and S. Snider. 1967. Modification of the curcumin method for low level boron determination. Analyst 92:532-533.

Knudsen, D., G.A. Peterson, and P.F. Pratt. 1982. Lithium, sodium, and potassium, p. 225-246. In: A.L. Page, R.H. Miller, and D.R. Keeney (eds.). Methods of soil analysis, part 2: Chemical and microbiological properties. 2nd ed. Amer. Soc. Agron./Soil Sci. Soc. Amer., Madison, Wis.

Lin, Y., E.J. Holcomb, and J.P. Lynch. 1996. Marigold growth and phosphorus leaching in a soilless medium amended with phosphoruscharged alumina. HortScience 31:94-98.

Lynch, J., E. Epstein, A. Lauchli, and G.I. Weigt. 1990. An automated greenhouse sand culture system suitable for studies of P nutrition. Plant Cell Environ. 13:547-554.

Marconi, D.J. and P.V. Nelson. 1984. Leaching of applied phosphorus in container media. Scientia Hort. 22:275-285.

Mills, H.A. and J.B. Jones, Jr. 1996. Plant analysis handbook II: A practical sampling, preparation, analysis, and interpretation guide. Micro-Macro Publishing, Athens, Ga.

Murphy, J. and J.F. Riley. 1962. A modified single solution method for the determination of phosphate in natural waters. Anal. Chim. Acta 27:3136.

Nelson,P.V.1998. Greenhouse operation and management. 5thed.PrenticeHall, Upper Saddle River, N.J.

Niedziela, C.E. and P.V. Nelson. 1992. A rapid method for determining physical properties of undisturbed substrate. HortScience 27:1279-1280.

Nishimoto, R.K., R.L. Fox, and P.E. Parvin. 1975. External and internal phosphate requirements of field-grown chrysanthemums. HortScience 10:279-280.

Olsen, S.R. and L.E. Sommers. 1982. Phosphorus, p. 403-430. In: A.L. Page, R.H. Miller, and D.R. Keeney (eds.). Methods of soil analysis. part 2: Chemical and microbiological properties. 2nd ed. Amer. Soc. Agron./ Soil Sci. Soc. Amer., Madison, Wis.

Pyle, K. 1991. Water contamination regulation: What lies ahead for greenhouse growers? GrowerTalks 55(5):18-21.

Sposito, G. 1984. The surface chemistry of soils. Oxford Univ. Press, New York.

U.S. Environmental Protection Agency. 1989. Report to Congress: Water quality of the nation's lakes. EPA 440/5-89-003, U.S. EPA, Wash., D. C.

Warncke, D.D. and D.M. Krauskopf. 1983. Greenhouse growth media: Testing and nutrition guidelines. Mich. State Univ. Coop. Ext. Bul. E1736.

Williams, K.A. and P.V. Nelson. 1992. Low, controlled nutrient availability provided by organic waste materials for chrysanthemum. J. Amer. Soc. Hort. Sci. 117:422-429. 